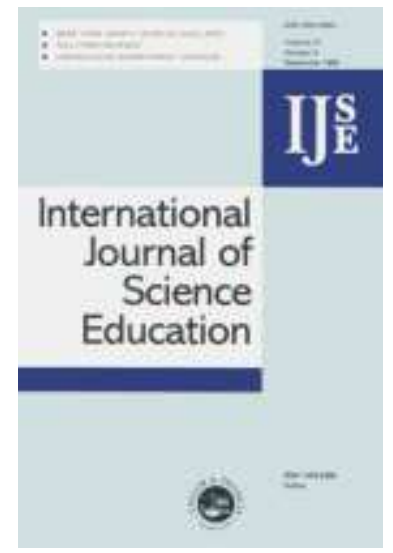

\title{
The Nature of Science Education for enhancing Scientific Literacy
}

\begin{tabular}{|r|l|}
\hline Journal: & International Journal of Science Education \\
\hline Manuscript ID: & TSED-2006-0123.R1 \\
\hline Manuscript Type: & Research Paper \\
\hline Keywords: & nature of science, position paper, science education \\
\hline Keywords (user): & $\begin{array}{l}\text { Nature of science education, Education through science, Scientific } \\
\text { and technological literacy }\end{array}$ \\
\hline
\end{tabular}

\section{S) ScholaroNE" \\ Manuscript Central}




\title{
The Nature of Science Education for enhancing Scientific Literacy
}

Jack Holbrook and Miia Rannikmae, University of Tartu, Estonia

\begin{abstract}
This article explores the meaning of the nature of science education to enhance scientific literacy. It argues that the teaching approach for science education should be regarded as "education through science, rather than "science through education". A model of the nature of science education is proposed having its foundations based on activity theory rather than logical positivism. This encompasses an understanding of the nature of science, with links to achievement of goals in the personal domain, stressing intellectual and communication skill development, as well as the promotion of character and positive attitudes, plus achievement of goals in the social education domain, stressing cooperative learning and socio-scientific decision making. Although the nature of science is seen as an important component of science education, the over-riding target for science teaching in school, as an aspect of relevant education, is seen as responsible citizenry, based on enhancing scientific and technological literacy. The meaning of scientific and technological literacy is discussed.
\end{abstract}

\begin{abstract}
Key words - nature of science education, nature of science, education through science, true or multi-dimensional scientific and technological literacy, relevant education, activity theory.
\end{abstract}




\section{Introduction}

A common rationale given for studying science subjects in school is the achievement of scientific literacy (AAAS, 1989; Bybee, 1997; OECD, 2003, Brown, Reveles \& Kelly, 2005; Shwartz, Ben-Zvi, and Hofstein, 2005), although there are different interpretations of its meaning (Jenkins, 1990; DeBoer, 2000; Laugksch, 2000; Tippens, Nichols \& Bryan, 2000; Kolstø, 2001; Hodson, 2002; Fensham, 2004). This paper sets out to establish the nature of science education needed to prepare students for the kind of scientific literacy necessary for responsible citizenship. It proposes that abilities in a range of educational goals including socio-scientific decision making and scientific problem solving are more important for enhancing true scientific literacy (Shamos, 1995), or multi-dimensional scientific literacy (Bybee, 1997) than a thorough basic understanding of fundamental content knowledge (AAAS, 1993; NRC, 1996).

A model is put forward for the nature of science education which is based on educational needs, as determined by the curriculum, and leads to an approach through which "education through science" is perceived as a more appropriate description of the teaching emphasis than science through education. Teaching based on this model is less about post positivism or constructivist approaches and more related to activity theory (Roth and Lee, 2004; van Allsvoort, 2004a; 2004b) where student needs and student motivation, and hence interest, form the major focus. The encompassing teaching framework is thus one of increasing the relevance of science education (Fensham, 2004) in the school situation from both an educational and societal perspective. 
This paper recognises that the ideas proposed are really applicable to secondary (beyond grade 6) more than primary education. It accepts that at the primary education level student interest in science is generally positive and, at that level, science, reflected as investigational science, can bring great enjoyment to students as they explore, in a concrete manner, many scientific ideas. As Osborne, Simon and Collins (2003) point out:

'a clear feature of science education research is the decline in attitudes towards science from age 11 onwards. This is documented by a number of studies which all show how children's interest and attitude to science declines from the point of entry to secondary school. The evidence would suggest that children enter secondary school/junior high with a highly favourable attitude towards science and interest in science, both of which are eroded by their experience of school science, particularly for girls (Kahle and Lakes, 1983). Such findings need to be qualified by the rider that other research shows that attitudes to all subjects decline in general during adolescence (Eccles and Wigfield, 1992; Epstein and McPartland, 1976)'

It is with the need to further develop reasoning skills and to draw conclusions (Sadler 2004; Sadler and Zeidler, 2005), to guide students to develop argumentation skills (Driver, Newton \& Osborne 2000 ; Osborne, Erduran \& Simon, 2004) and to make judgemental decisions utilising scientific ideas (Ratcliffe, 1997; Kortland, 2001) that science education becomes problematic and there is the danger that an over-emphasis on content overshadows acquisition of educational goals and thus inhibits the promotion of multidimensional levels of scientific literacy (Bybee, 1997) for functioning within society. 
Science education, at the secondary level (grade 7 and above), is firmly included as a component of the education provision virtually worldwide. In most curricula, and through perceptions held by the majority of teachers, science education is seen as building on logical positivism ideas (van Aalsvoort, 2004a) in propogating scientific information and concepts as a theoretical component on the one hand and an observational language on the other. This implies that science teaching is seen as relating to the observation of phenomena which are then generalised into theories and these theories supported by further observation. There is a cycle of teaching, often promoted as hypothetico-deductive, which calls for observations to be generalised into well known laws or theories and for laws and theories to be supported by carrying out observations. The theoretical ideas underpinning this are thus about the rationality of results already existing, rather than new discoveries. As suggested by van Aalsvorst (2004a), such a theoretical underpinning inhibits rather than promotes relevancy of science teaching in the eyes of students. The science teaching focus is from an understanding of what is important from a scientist's perspective rather than from the viewpoint of the learner, or society. It calls upon students to act as 'little scientists', even though they have yet to master the problem solving and decision making skills which are an integral part of their science learning. This focus can be summarised as shown in table 1. Such an approach is not advocated in this paper, nor seen as the substance for promoting meaningful scientific literacy.

Table 1 about here

Besides the decline in student attitudes towards science (Osborne et all, 2003), an appropriate teacher understanding of the nature of science education is likely to be suspect and linked to this, the manner in which science teaching includes understanding of the nature of science (Lederman, Wade \& Bell, 1998). While there is no universal conceptualisation of the nature of science (Kang et al., 2005; Scharmann \& Smith, 2001) and as Suchting (1995) has argued, views on the nature of science are likely to evolve as science grows, there does seem to be 
broad general agreement that the nature of science should be recognised as a human endeavour (the human fallibility has been limited, but not entirely eliminated), tentative (subject to change, as the knowledge is not proven, but simply not falsified), empirical (based on and/or derived from observations of the natural world although these are theory-laden), include human inference (as distinct from observation), imagination, and creativity (putting forward explanations), and be socially and culturally embedded (Lederman et al. 1998; Hand et al., 1999; Bell and Lederman, 2003; Schwartz et al., 2004: Abd El Khalick, 2005; Kang et al., 2005). The fact that observation and experiment are the only basis on which science is built lends support to rational activity constituting knowledge claims through argumentation, but does not eliminate the human or social aspects and goes some way to suggesting why studies in areas such as sociology, economics and civics can be considered as a science under the heading of social science.

\section{The Nature of Science Education}

In most educational systems, science education is an integral part of the total education provision within a school. It may be argued that different subjects should cover different educational domains, or perhaps sub-domains (for example, language subjects covering the development of communication skill; mathematics used to teach logic; social science covering the teaching of cooperative learning or social values and science teaching psychomotor and problem solving skills), but this cannot be realistic, given that choice of subjects within the curriculum is often practiced. Assuming the education provision needs to be covered across the range of educational skills in the combination of subjects selected by students, it therefore seems logical that all subjects taught need to relate to the full spectrum of educational goals. By recognising that science education is part of the education provision within schools, the teaching of science subjects can be expected to promote the development of a range of skills 
and values, identified within the educational goals and especially to enable students to solve problems, in this case, of a scientific nature and make appropriate socio-subject decisions, in this case socio-scientific (Holbrook \& Rannikmäe, 2002). The nature of science education is thus far more than an understanding of the nature of science.

In the past, the domains of education were sub-divided into cognitive, affective and psychomotor (Bloom, 1956), especially when considering the teaching of science subjects. The cognitive domain included the development of thinking skills and could also be said to include problem solving skills and reasoning abilities. However, creativity in an artistic sense, interest, personal development and various forms of dexterity applied in an appropriate context (e.g. practical work) are related to the affective and psychomotor domains. Today, however, a wider view of educational components are more likely and cover intellectual, communicative, social and moral, cooperative, personal and physical skills, as well as attitudes (Curriculum Development Council, 1995).

The Bloom categorisation of educational goals into cognitive, affective and psychomotor components has not been empirically derived from the way students learn, but rather from opinions by educators (Biggs, 1996). However, while other taxonomies, such as SOLO (Biggs, 1996) derive from observed student learning outcomes, they do not match the education goals as specified in curricula. Where these goals cover intellectual and communicative skills, together with personal development and attitudes, these can be considered as components of an individual, or personal, domain. They all pertain to the development of the individual. On the other hand, cooperative learning, which obviously takes place in a group and social, ethical and moral values relating to interactions and decision making within society, can be taken as components of a society domain. This condensation allows the sub-divisions of educational 
goals to be regrouped into three revised components - a Personal domain, a Society domain, plus a domain geared to attributes of the subject. For science, it is proposed that the attributes of the subject are provided through acquiring an understanding of the Nature of Science in meaningful contexts, linked to enquiry teaching and problem solving investigations.

The Nature of Science Education can thus be perceived as a 3 domain representation, as illustrated in figure 1:

Figure1 about here

From this figure, the nature of science education is clearly portrayed as more than an understanding the nature of science, or acquisition of scientific ideas. The nature of science education puts the learning of the nature of science into an educational framework. It links the nature of science with the full spectrum of educational goals described earlier under the domains of personal and society developments. This is proposed as a major change of focus for classroom implementation and also for the assessment of student achievements in the discipline of science education. It suggests the teaching of science subjects is through a 3 domain educational structure, not simply through science content and such a structure forms the focus for the enhancement of scientific literacy through formal schooling.

In putting forward this model for the nature of science education, the acquisition of the "big" ideas in science has been relegated to building a concept of the nature of science and/or the promoting of personal intellectual thinking. The fundamental building blocks of science by themselves, or the "big" ideas as expounded by AAAS (1993) and NRC (1996), are not seen as crucial elements of scientific literacy. This does not mean they are excluded from the teaching of science, but it is a recognition that useful basic knowledge is tentative, liable to regional variations and best included on a need-to-know basis (where the need for knowledge has 
previously been identified). This will mean that the curriculum logic based on the "fundamental" ideas no longer forms the basis for teaching. Rather complex issues and situations within society, the so called socio-scientific issues (Sadler and Zeidler, 2005; Zeidler et al, 2005) are seen as the starting points for science learning. This allows personal and social components of learning to play a relevant and motivational role in the enhancement of scientific literacy among students. And leading on from this, it is proposed that the teaching of science subjects is through context based situations and not through the identification of essential content. Such a view represents a major change of focus for the teaching of science subjects and suggests that no content is fundamental, but rather the content needed for enhancing scientific literacy is dependent on the culture and societal in which the science education is being implemented. This, it is claimed, is true even noting the current spread of globalization and the increased mobility of people across cultural divides.

The key driving force for the nature of science education is the need for students to acquire social skills, supported by individual skills, thus enabling students (and later as adults - Roth and Lee, 2004) to play a responsible role within society in terms of

(a) developing social values such that a person can act in a responsible manner within the community, system, nation or, as in the school situation, at a smaller group level;

(b) being able to function within the world of work at whatever the skill or responsibility level;

(c) possessing the conceptual background or skills of learning to learn to cope with a needto-have, relevant public understanding of science and technology in a changing society. These are the essence of enhancing true (Shamos, 1995) or multi-dimensional (Bybee, 1997) scientific literacy. $\checkmark$

\section{Education through Science}

Deleted: hitherto

Deleted: s

Deleted: suggested to be 
Teachers are educators. Education is the area of focus for science teachers and the science is merely the vehicle for this. The term 'education through science' is proposed to express the intentions for the teaching-learning approach geared to the nature of science education advocated in this article. The proposed nature of science education is thus not about stressing the ways of the scientist any more than history is taught for students to become historians, or language is taught to become linguists. It is proposed that science in school is part of the education provision and any science content is gained so as to enhance that education in the nature of the subject, the personal or the social domains. Table 2 below illustrates a comparison of 'education through science' with 'science through education' - the alternative if in the short term, nature of science, or a content approach to science teaching, is the sole basis for the nature of science education proposed.

Table 2 about here

While the inclusion of personal and society domains into the learning structure are expected to enhance the relevance of science teaching, the approach is not explicit and the need for a stronger theoretical construct is needed. This is provided by activity theory.

\section{The Nature of Science Education and Activity Theory}

In recognising the trend towards education through science, van Aalsvoort (2004b) proposes activity theory to replace logical positivism as the tool to address the lack of relevance of school science. This approach is strongly reinforced by Roth and Lee (2004). The theory is based on the interlinking of knowledge and social practice through establishing a need (relevant in the eyes of students), identifying the motives (wanting to solve scientific problems and make socio-scientific decisions) leading to activity constituted by actions (learning in school towards becoming a scientifically literate, responsible citizen). The activity model is appropriate for realising the goals of education, although van Aalsvoort's examples do not 
attempt inclusion of the personal and social domains of education. His examples, although society related, are subject specific and do not involve socio-scientific decision making linked to the reflection stage directly (the decision are scientifically oriented and do not dwell, for example, on environmental, economic or ethical factors). On the other hand, Roth and Lee (2004) see activity theory forming a theoretical base for developing scientific literacy integrating the society need and the interrelated subject need. They postulate that activity theory is particularly appropriate for theorising participation and learning across multiple, heterogeneous settings (Chaiklin \& Lave, 1993; Engestr'om, Miettinen \& Punam'aki, 1999).

In activity theory, activities constitute the unit of analysis (Roth and Lee, 2004). The basis of the activity theory revolves around three levels of activity (van Aalsvoort, 2004b), namely

1. the level of activity proper,

2. the level of actions, and

3. the level of operations.

Besides this, the development of an activity and a recognition of the role of scientific concepts depends on reflection as this important step allows evaluation of the activity and its results.

The level of an activity proper can be interpreted as science-related social practices (van Aalsvoort, 2000). Such practices are meant to provide for student needs (as perceived by students insofar as this is possible, otherwise perceived by society as an area of need) in a more or less organized way by making 'products' or 'decisions' from 'raw materials', scientific components, or issues to resolve. The activity can be 'enquiry process' or 'debate'. These practices may be characterized by a number of motives, because scientific problem solving $\underline{\text { results from wanting to determine a solution which, in turn, can feed a decision making process }}$ linked to the students' need for resolving a social issue, van Aalsvoort (2004b) used the need
Deleted: and

Deleted: $\mathrm{h}$

Deleted: and issue-based

Deleted: as explicit examples

Deleted: aw

Deleted: a societal described

Deleted: highlighted

Deleted: the

\section{Deleted:}

Deleted: o 
for water as the issue of socal concern, the production of drinking water from suitable raw materials as the problem solving comoponent and centred the decision making on the type of waterworks to design.

At the level of actions, the division of labour is the usual social practice and cooperative learning within groups is the usual action within the clasroom. The motive (wanting to decide) or the goal (learning to decide) relates to deciding the best choice, taking into consideration the needs of all members of the society.

Operations concern the techniques and routines that are characteristic for the carrying out of the actions. In the classroom, these involve the plans and procedures for problem solving, but in society they can involve experts in experimental procedures, or ways for the presentation of outcomes.

“For example, articles and reports have a certain arrangement, and talks are given according to certain conventions. The techniques and routines, which are to be used, depend on objective circumstances, for instance, the availability of apparatus, the properties of substances chosen, scientific requirements with respect to experimental procedures - cultural conditions for short. It is important to notice that cultural conditions are not unchangeable, but that they change over time. Moreover, they are often the outcome of other social practices. A telling example is the availability of apparatus mentioned earlier.“(van Aalsvoort, 2004b)

\section{Reflection}

In the framework of science-related practices, reflection has the function of bringing about improvements in a practice, or a decision. These may concern the quality of products,
Deleted: routines in the form of

Deleted: results

Formatted: Font: Italic

Formatted: Indent: Left: $35.4 \mathrm{pt}$, Hanging: $0.6 \mathrm{pt}$

Deleted: matter 
processes to be used, or the choices to be made. Reflection takes place using, among others, science concepts as tools.

Reflection plays an important role in learning according to activity theory. This holds for practice as well as decisions made. Reflection can take the shape of planning a course of action, justifying what one is planning to do or has done, and comparing two courses of action. It should be noted that, according to a sociocultural approach, reflection does not happen in the mind of an individual only. Rather, reflection takes place when people cooperate on a task. In this, language is a tool that creates the possibility of thinking and organizing thought processes. In the example by van Aalsvoort (2004b), reflection is geared to reasons put forward for the $\underline{\text { choice of raw materials for the production of drinking water and, later, reflection looks back at }}$ any problems associated with the purification process chosen.

\section{The learner}

In this approach, it is interesting to note that the learner is considered an apprentice. This is to say that the learner participates in a practice, although at first, participation takes place in a school version of the practice. An apprentice cannot be expected to carry out tasks in a professional way. Again van Aalsvoort (2004b) illustrates this by the use of coloured water, rather than the more realistic water containing pesticides, in the purification of water, allowing students to be guided to take on the role of chemical analysts more safely in determining whether the purified water prepared meets the requirements of the law.

Activity theory, therefore, assumes that social practices develop due to interplay between the above practices. For this science education needs to involve students in identifying and carrying out activities related to their needs (or the needs perceived by society which are 
relevant to student learning). In the classroom, addressing the need are not driven by considerations of completing a curriculum or preparation for an examination, but heavily related to relevance in an educational sense. Roth and Lee (2004) likened the activity theory to a rope with threads and fibres. The community of practice or the society are represented by the rope; the persons involved are the threads, and the various knowledge and skills held by the individuals are the fibres.

\section{Meaning of Scientific and Technological Literacy (STL)}

As indicated in the introduction, the teaching of science in school is taken to be the enhancing of scientific literacy. The nature of science education is such that it provides the framework for formal education to focus in this direction. It is now time to try to clarify the meaning of scientific literacy. As a start, noting that developments within society are largely of a technological nature, it is proposed that it is more appropriate to consider scientific and technological literacy when referring to education through science (UNESCO, 1993). In the school context, it is extremely difficult to distinguish between scientific literacy and technological literacy, as the two go together (technology is not intended to simply refer to computers, or the simple acquisition of technical skills, but to the man-made materials and processes developed within society). In fact, for all practical purposes related to the teaching within schools, scientific literacy and technological literacy can be taken to be the same. This does not mean that science is the same as technology, far from it. But it does suggest that the conceptual knowledge, personal and society values inherent in the development of STL in this sense are indistinguishable. The only difference in the teaching of science and the teaching of technology is in the nature of science, as opposed to the nature of technology. 
While communication skill is a crucial component of literacy - referred to as literacy in its fundamental sense, rather than a derived sense, by Norris and Phillips (2003) - it is difficult to see how any approach to STL is bound simply by language, or by a dominance of the written text. Language ability, as a component of communication skill, is itself part of the personal domain in the model for the nature of science education detailed earlier and is thus common to learning in all subject areas, not just science education. Scientific and technological literacy is much more than language proficiency, as the French translation of scientific and technological literacy as "culture scientifique et technologique "(UNESCO 1994) strongly suggests.

Deleted: culture The foundation of STL inevitably relates to the conceptualisation of need-to-know scientific knowledge, although many school curricula seem to place higher emphasis on developing a far wider knowledge component than is warranted for a subject area expanding at a faster and faster pace (Schibeci \& Lee, 2003). Knowledge for its own sake, and hence communication linked to such knowledge (Norris and Phillips, 2003), needs to give way to knowledge and communication for functionality in society and this is likely to be culturally and even regionally bound.

STL is expected to indicate an ability to function, or the potentiality to function, within society (Kolsto,2000, Millar,1996) This can cover an understanding of the science underpinning the technological advances of today, but that is a gigantic undertaken and beyond the ability of any one person (Shamos, 1995). Global understanding of science in society cannot be seen as a target for school science education. Rather STL is related to an awareness of the science within society and an awarensss of experts who can provide the understanding that the ordinary citizen may lack (Shamos, 1995, DeBoer, 2000). But that still does not cover the enabling of decisions to be made in a democratic society, where science driven technology is playing a 
greater and greater role. Nor does it develop an appreciation that the advantages of technological developments can be great for some, but a major disadvantage for others and where side-affects related to health, the sustainability of the environment, or economic concerns can become key factors in choosing the most appropriate science-driven technology (Roth and Lee, 2004; Sadler and Zeidler, 2005). STL is seen as embracing all of this.

STL is a simple term and its major advantage is that it can be used to sum up, at the school level, the intentions of science education (AAAS, 1989; NRC, 1996) and highlight the nature of science education needed. It avoids the use of distracting detail and, as such, convincingly portrays a complex idea which intuitively appears to be correct (Baumert, 1997). But it suffers from two divergent visions:

a) those who advocate a dominant role for specific ideas in science, promoted within an understanding of the nature of science (AAS, 1993; NRC, 1996) and. hence focus the nature of science education on an understanding of the science within society;

b) those who see the nature of science education predominantly linked to promoting the functionality of a citizen within society (Roth and Lee, 2004).

The first camp seems to be very prevalent among science teachers today. It builds on the notion that there are fundamental ideas in science which are essential and that this is required in building a concept of the nature of science. The nature of science education is dominated by the conceptual science component and scant attention is focussed on personal and social aspects. A science dominant nature of science education has been described as a short term view (Maienschein, 1998) and even labelled as "science literacy" to distinguish it from a longer term view of "scientific literacy". 
The second vision sees STL as a requirement to be able to adapt to, and play a responsible role in, the challenges of a rapidly changing world. It recognises the need for reasoning skills in a social context which are based on sound scientific ideas, derived from conceptual understanding and linked to the nature of science. And above all, this view recognises that STL is for all (Roth and Lee, 2004) and has little to do with science teaching solely focusing on a career in science, or solely providing an academic science background for specialisation in science. This second view essentially refutes the need for two types of school science courses one for general education and another for specialists - and recognises that a specialist course would simply be an extension of the former with an increase of "time on task" - that is, more science lessons (Holbrook, 1998). This direction sees responsible citizenry as a major focus, in which scientific knowledge is used wisely for the benefit of society. Roth and Lee (2004) and others (Jenkins, 1999) have called this citizen science. It strongly includes the personal and social domains alongside the nature of science. And while its teaching is in the context of education through science and is issue-based or context-based (Zeidler et al., 2005), the scientific ideas are limited to the issue in hand, However it does not eliminate the inclusion of a historical perspective, nor exclude teacher knowledge inputs alongside student constructivist learning.

"School science education needs to respond to a changed social context and to help prepare young people to contribute as citizens to shaping the world in which they will live“ (Jenkins, 1999).

To succeed leads to a well informed, responsible citizenry in the future. To get the provision of appropriate school science wrong, and indicators suggest this is the current sitation (European Commission, 2004), leads to irrelevant curricula, an unpopular subject and a lack of student interest. Where high stakes, pencil and paper, summative examinations are the sole assessment 
measures, the assessment of the real nature of science education and hence the relevance of school science is always likely to be in danger, as personal and social learning is omitted from the assessment and most probably from implementation in the classroom.. In such a situation, it is difficult to perceive how this can detract from the current unpopularity of the subject (European Commission, 2004). Nor will such summative assessment, necessarily lead to a better informed society capable of making decisions.

It is thus proposed that the trend in defining STL is away from the short term scientific knowledge as a product approach, in which the facts and skills are paramount, towards

(a) inclusion of issue-based or context-based teaching as a major thrust to 'set up' the scientific problem to be investigated (Zeidler et al, 2005);

(b) the need to go beyond scientific problem solving (related to appreciating the nature of science and through enquiry, acquiring relevant process skills) to also encompass socioscientific decision making (related to responsible citizenry and public understanding of science even if this is related to the public understanding of science),

(c) recognition that scientific literacy relates primarily to enabling citizens to effectively participate in the real world and is thus a social rather than an individual consideration (Roth and Lee, 2004).

A single, simple definition of STL or scientific literacy building on the model of the nature of science education as expounded is always likely to be extremely problematic. The OECD (2003) PISA study suggested:

\footnotetext{
"the capacity to use scientific knowledge, to identify questions and to draw evidencebased conclusions in order to understand and help make decisions about the natural world and the changes made to it through human activity".
} 
The emphases on drawing conclusions and decision making suggest an understanding of the nature of science and the inclusion of a social domain are key components in their ideas of the nature of science education. Developing the capacity to use scientific knowledge also indicates the development of intellectual skills of the person and points to the nature of science education encompassing a personal domain.

The inclusion of a social and personal domain concept of scientific literacy also comes through from the ICASE-UNESCO forum on scientific and technological literacy for all (UNESCO, 1993), which suggested scientific literacy as:

"the capability to function with understanding and confidence, and at appropriate levels, in ways that bring about empowerment in the man-made world and in the world of scientific and technological ideas”.

A later definition by ICASE, intended to involve the nature of science, the personal and the social domains, but also stressing socio-scientific decision making, is (Holbrook and Rannikmae, 1997):

"developing the ability to creatively utilise sound science knowledge in everyday life, or in a career, to solve problems, make decisions and hence improve the quality of life".

\section{Conclusion}

Apreciation the nature of science education is important for the way science subjects are portrayed and taught in school. The nature of science eduction is, of course, governed by the curriculum, and especially the stated overall goals of education, but is currently being poorly expressed in relation to these overall goals. Unless teachers have a clear idea of the nature of science education, it is unlikely they can fulfill the demands of society in implementing the education intended. 
Important also is the focus of scence education if it is to enhance students' acquisition of scientific and technological literacy as expressed by Shamos (1995) and Bybee (1997). There is a need to move away from a content led teaching direction to one that focusses on the needs and motives of students for learning through science subjects. This can be expressed as societyfocussed, socio-scientific issues led (Zeidler \& Keffer, 2003), education through science, where the science is merely the vehcle for the learning.

What is not explicitly expressed by the nature of science education, and will always be dependent on a variety of factors, is the emphasis to be given in science education to each of the educational domains and the classoom atmsphere in which teaching is made interesting and motivational for students.

Developing science curricula, based on a nature of science education, in which the domains of the nature of science, the personal domain and the social domain, linked to activity theory, is put forward as a direction of promise. It is proposed as an approach for relevant science education and the enhancement of true or multi-dimensional scientific literacy for a future society.

\section{References}


ABD-EL-KHALICK F. (2005). Developing deeper understandings of nature of science: the impact of a philosophy of science course on preservice science teachers' views and instructional planning. International Journal of Science Education, 27(1), 15-42.

ABD-EL-KHALICK F., BELL, R.L., \& LEDERMAN, N.G. (1998). The Nature of Science and institutional practice: Making the unnatural natural. Science Education, 82, 417-436.

AMERICAN ASSOCIATION FOR THE ADVANCEMENT OF SCIENCE [AAAS]. (1989). Science For All Americans. A Project 2061 Report on Literacy Goals in Science, Mathematics, and Technology. (Washington, D.C.: AAAS).

AMERICAN ASSOCIATION FOR THE ADVANCEMENT OF SCIENCE [AAAS]. (1993). Benchmarks for Scientific Literacy. (Oxford: Oxford University Press).

BAUMERT, J. (1997). Scientific Literacy: A German Perspective. In W. Graber and C. Bolte. (eds). Scientific Literacy: An International Symposium, (Germany: IPN). 167-180.

BELL, R.L. \& LEDERMAN, N.G. (2003). Understanding of the Nature of Science and Decision Making on Science and Technology Based Issues. Science Education, 87, 352377.

BIGGS, J. (ed). (1996). Testing: To Educate or to Select? Hong Kong at the Crossroads. Hong Kong: Hong Kong Educational Publishing Co.

BLOOM, B. (ed.) (1956). Taxonomy of Educational Objectives. The classification of educational goals. Handbook 1, cognitive domain. (New York, Toronto: Longman Green). BROWN, B. A., REVELES., \& J. M. KELLY, G. J. (2005). Scientific Literacy and Discursive Identity: A Theoretical Framework for Understanding Science Learning. Science Education, 89.

BYBEE, R (1997). Towards an Understanding of Scientific Literacy. Scientific Literacy: Science Education and Secondary School Student. In W. Graber and C. Bolte. (eds.) Scientific Literacy: An International Symposium, (Germany: IPN). 37-67. 
CHAIKLIN, S., LAVE, J. (eds.) (1993). Understanding practice: Perspectives on activity and context. (Cambridge, England: Cambridge University Press).

CURRICULUM DEVELOPMENT COUNCIL [HONG KONG]. (1995). Guide to the

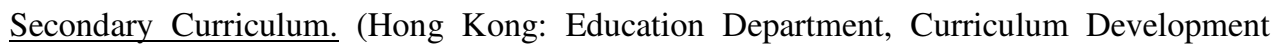
Institute).

DEBOER, G.E. (2000). Scientific Literacy: Another Look at Its Historical and Contemporary Meanings and Its Relationship to Science Education Reform. Journal of Research in Science Teaching, 37(6).

DRIVER, R., NEWTON, P., \& OSBORNE, J. (2000). Establishing the norms of scientific argumentation in classrooms. Science Education, 84(3), 287-312.

ENGESTR'OM, Y., MIETTINEN, R., \& PUNAM'AKI, R-L. (1999). Perspectives on activity theory. (Cambridge, England: Cambridge University Press).

EUROPEAN COMMISSION. (2004). Europe needs more scientists. Report by the High level Group on Increasing Human Resources for Science and Technology in Europe. (Belgium: European Commission, Information and Communication Unit).

FENSHAM, P.J. (2004). Increasing the Relevance of Science and Technology Education for all student in the 21st century. Science Education International, 15(1), 7-27.

HAND, B.M., PRAIN, V., LAWRENCE, C., \& YORE, L.D. (1999). A writing in a science framework designed to enhance scientific literacy. International Journal of Science Education, 21, 1021-1035.

HODSON, D. (2002). Some thoughts on Scientific Literacy: Motives, meanings and curriculum implementations. Asia-Pacific Forum on Science Learning and Teaching, vol. 3 , issue 1 .

HOLBROOK, J. (1998). Operationalising Scientific and Technological Literacy - a new approach to science teaching. Science Education International. 9(2). 
HOLBROOK, J., \& RANNIKMÄE, M. (eds.) (1997). Supplementary Teaching Materials Promoting Scientific and Technological Literacy. (Tartu, Estonia: ICASE).

HOLBROOK, J., \& RANNIKMÄE, M. (2002). Scientific and Technological Literacy for all - an Important Philosophy for the Teaching of Science Subjects. In K.Ninisto, H.Kukemelk \& L.Kemppinen. (eds.) Developing Teacher Education in Estonia. (Turku, Finland: University of Turku).

JENKINS, E. (1999). School science, citizenship and the public understanding of science. International Journal of Science Education, 21, 703-710.

JENKINS, E. (1990). Scientific literacy and school science education. School Science Review, 71(256), 43-51.

KANG, S., SCHARMANN, L.C., \& NOH, T. (2005). Examining Students' Views on the Nature of Science: Results from Korean 6th, 8th and 10th Graders. Science Education, 89, 314-334.

KOLSTØ, S.D. (2001). Scientific literacy for citizenship: Tools for dealing with the science dimension of controversial socio-scientific issues. Science Education, 85, 291-310. KOLSTØ, S.D. (2000). Consensus Projects: Teaching science for citizenship. International Journal of Science Education, 22, 645-664.

KORTLAND, K. (2001). A problem posing approach to teaching decision-making about the waste issue. CD- $\beta$ series, vol. $37, \mathrm{CD}-\beta$ press, Universiteit Utrecht, Utrecht, Netherlands

LAUGKSCH, R.C. (2000). Scientific literacy: a conceptual overview. $\underline{\text { Science Education, }}$ 84(10), 71-94.

LEDERMAN, N. G., WADE, P. D., \& BELL, R. L. (1998). Assessing the nature of science: What is the nature of our assessments? Science and Education, 7(6), 595 -615.

MAIENSCHEIN, J. (1998). Scientific Literacy. Science Magazine, 281, issue 5379, pp917. 
MILLAR, J. D. (1996). Scientific Literacy for Effective Citizenship. In Robert E. Yager (ed). Science/ Technology/ Society as Reform in Science Education. (Albany, New York: SUNY Press).

NORRIS, S.P., \& PHILLIPS, L.M. (2003). How Literacy in its Fundamental Sense is Central to Scientific Literacy. Science Education, 87, 224-240.

NATIONAL RESEARCH COUNCIL [NRC]. (1996). National Science Education Standards. (Washington D.C.: National Academy Press).

OECD (2003). The PISA 2003 Assessment Framework - Mathematics, Reading, Science and Problem Solving Knowledge and Skills. online:

www.pisa.oecd.org/dataoecd/46/14/33694881.pdf (accessed December, 2005).

OSBORNE, J. ERDURAN, S., \& SIMON S. 2004. Enhancing the quality of argumentation in school science Journal of research in science teaching, 41(10).

OSBORNE, J., SIMON, S., \& COLLINS, S. (2003). Attitudes towards science: a review of the literature and its implications. International Journal of Science Education, 25(9), 10491079.

RATCLIFFE, M., (1997). Pupil decision-making about socio-scientific issues within the science curriculum. International Journal of Science Education, 19, 2, 167-182.)

ROTH, W.-M., \& LEE, S. (2004). Science Education as/for Participation in the Community. Science Education, 88, 263-291.

SADLER, T. D. (2004). Informal reasoning regarding socio-scientific issues: A critical review of the literature. Journal of Research in Science Teaching, 41(4), 513-536. SADLER, T. D., \& ZEIDLER, D. L. (2005). Patterns of informal reasoning in the context of socio-scientific decision making. Journal of Research in Science Teaching, 42(1), 112138. 
SCHIBECI, R.., \& LEE, L. (2003). Portrayals of Science and Scientists, and 'Science for Citizenship'. Research in Science \& Technological Education, 21(2).

SCHARMANN, L. C., \& SMITH, M. U. (2001). Further thoughts on defining versus describing the nature of science: A response to Niaz. Science Education, 85(6), $691-693$.

SHAMOS, M. (1995). The Myth of Scientific Literacy. (New Brunswick, NJ: Rutgers University Press).

SCHWARTZ, R. S., LEDERMAN, N. G., \& CRAWFORD, B. A. (2004). Science teacher education developing views of nature of science in an authentic context: an explicit approach to bridging the gap between nature of science and scientific inquiry. Science Education, 88, 610-645.

SHWARTZ Y., BEN-ZVI, R., \& HOFSTEIN A. (2005). The importance of involving high-school chemistry teachers in the process of defining the operational meaning of 'chemical literacy'. International Journal of Science Education, 27(3), 323-344.

SUCHLING, W.A. (1995). The nature of scientific thought. Science and Education, 4(1), $1-22$.

TIPPENS, D. J., NICHOLS, S. E., \& BRYAN, L. A. (2000). International science educators' perceptions of scientific literacy. In S. K. Abell (ed.), Science teacher education: An international perspective. Dordrecht: Kluwer.

UNESCO. (1994). The Way Forward - STL for all. (Paris: Author).

UNESCO. (1993). International Forum on Scientific and Technological Literacy for All. Final Report. (Paris: Author).

VAN AALSVOORT, J. (2000). Chemistry in Products. A cultural-historical approach to initial chemical education. Ph.D. thesis. (Utrecht: Universiteit Utrecht). 
VAN AALSVOORT, J. (2004a). Logical positivism as a tool to analyse the problem of chemistry's lack of relevance in secondary school chemical education. International Journal of Science Education, 26(9), 1151-1168.

VAN AALSVOORT, J. (2004b). Activity theory as a tool to address the problem of chemistry's lack of relevance in secondary school chemical education. International Journal of Science Education, 26(13), 1635-1651.

ZEIDLER D.L., SADLER, T.D., SIMMONS, M.L., \& HOWES, E.V. (2005). A Research Based Framework for Socio-Scientific Issues Education. Science Education, 89(3), 357377.

ZEIDLER, D.L., \& KEFFER, M. (2003). The role of moral reasoning and the status of socio-scientific issues in science education: Philosophical, psychological and pedagogical considerations. In D.L Zeidler (ed). The role of moral reasoning and discourse on socioscientific issues in science education. (Netherlands: Kluwer). 
Table 1. Characteristics of science education when modelled on logical postivism (based on Van

28 Allsvoort, 2004a).

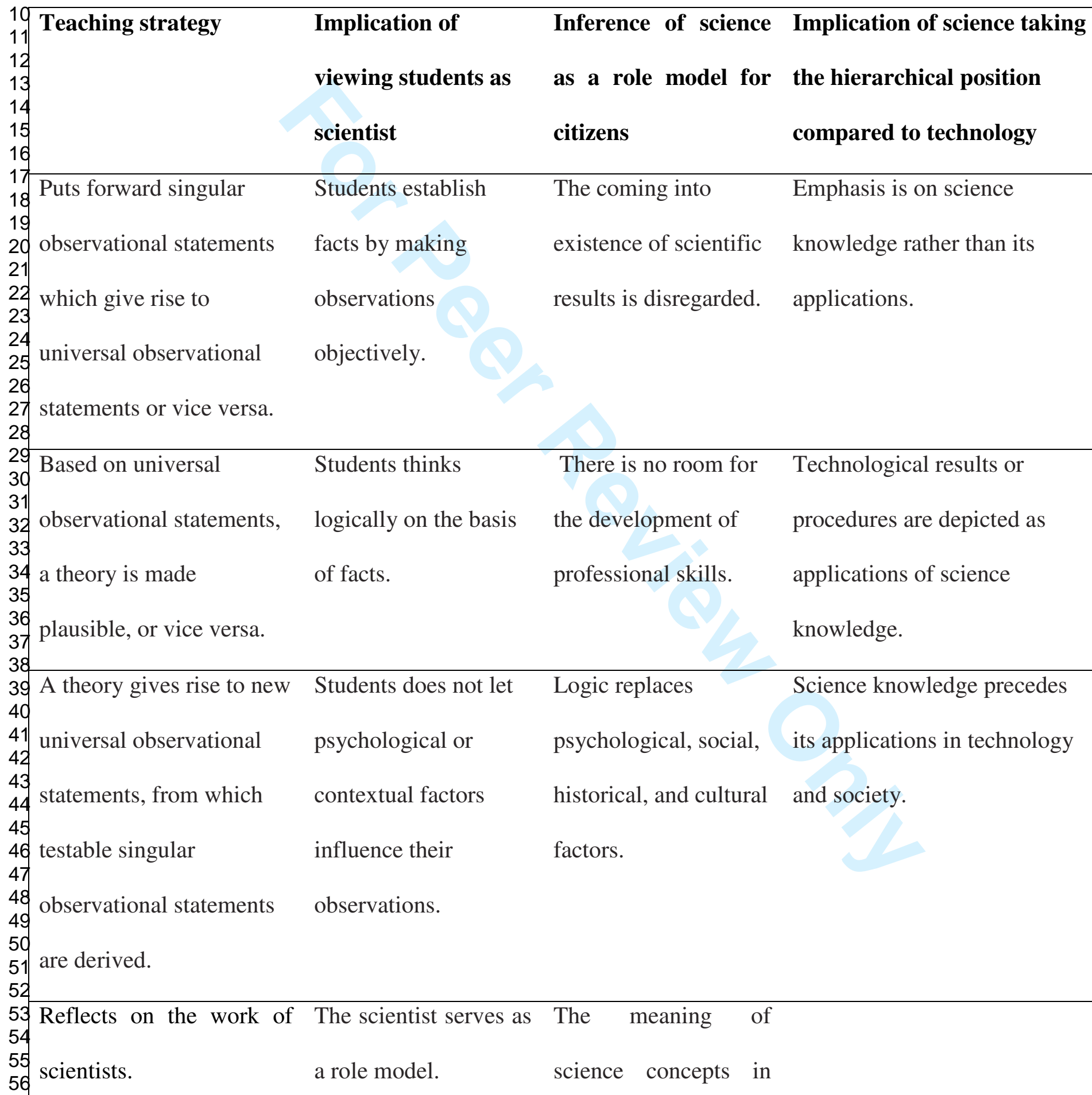

27 statements or vice versa.

Implication of viewing students as scientist

Students establish

facts by making

observations

objectively.

\section{Inference of science Implication of science taking} as a role model for the hierarchical position citizens

The coming into

existence of scientific knowledge rather than its results is disregarded. applications. 
ready-made science is

different from their

meaning in science in

the making.

Science education Science education can

deals with ready-made be typified as the

science rather than transmitting of

science in the making. science knowledge. 
Table 2. A comparison of similarities and differences in philosophical emphases between 'Science through Education' and the alternative 'Education through Science'.

\begin{tabular}{|c|c|}
\hline Science through Education & Education through Science \\
\hline $\begin{array}{l}\text { Learn fundamental science knowledge, } \\
\text { concepts, theories and laws. }\end{array}$ & $\begin{array}{l}\text { Learn the science knowledge and concepts } \\
\text { important for understanding and handling socio- } \\
\text { scientific issues within society. }\end{array}$ \\
\hline $\begin{array}{l}\text { Undertake the processes of science through } \\
\text { inquiry learning as part of. the development } \\
\text { of learning to be a scientist. }\end{array}$ & $\begin{array}{l}\text { Undertake investigatory scientific problem solving } \\
\text { to better understand the science background related } \\
\text { to socio-scientific issues within society. }\end{array}$ \\
\hline $\begin{array}{l}\text { Gain an appreciation of the nature of science } \\
\text { from a scientist's point of view. }\end{array}$ & $\begin{array}{l}\text { Gain an appreciation of the nature of science from a } \\
\text { societal point of view. }\end{array}$ \\
\hline $\begin{array}{l}\text { Undertake practical work and appreciate the } \\
\text { work of scientists. }\end{array}$ & $\begin{array}{l}\text { Develop personal skills related to creativity, } \\
\text { initiative, safe working, etc. }\end{array}$ \\
\hline $\begin{array}{l}\text { Develop positive attitudes towards science } \\
\text { and scientists. }\end{array}$ & $\begin{array}{l}\text { Develop positive attitudes towards science as a } \\
\text { major factor in the development of society and } \\
\text { scientific endeavours. }\end{array}$ \\
\hline $\begin{array}{l}\text { Acquire communicative skills related to oral, } \\
\text { written and symbolic/tabular/ graphical } \\
\text { formats as part of systematic science } \\
\text { learning. }\end{array}$ & $\begin{array}{l}\text { Acquire communicative skills related to oral, } \\
\text { written and symbolic/tabular/ graphical formats to } \\
\text { better express scientific ideas in a social context. }\end{array}$ \\
\hline Undertake decision making in tackling & Undertake socio-scientific decision making related \\
\hline
\end{tabular}


2

3

4

5

6

7

8

9 10

scientific issues. $\quad$ to issues arising from the society.

Apply the uses of science to society and Develop social values related to becoming a

appreciate ethical issues faced by scientists. responsible citizen and undertaking science-related careers. 
Figure 1 The Three Domains of Education (illustrated for science education)

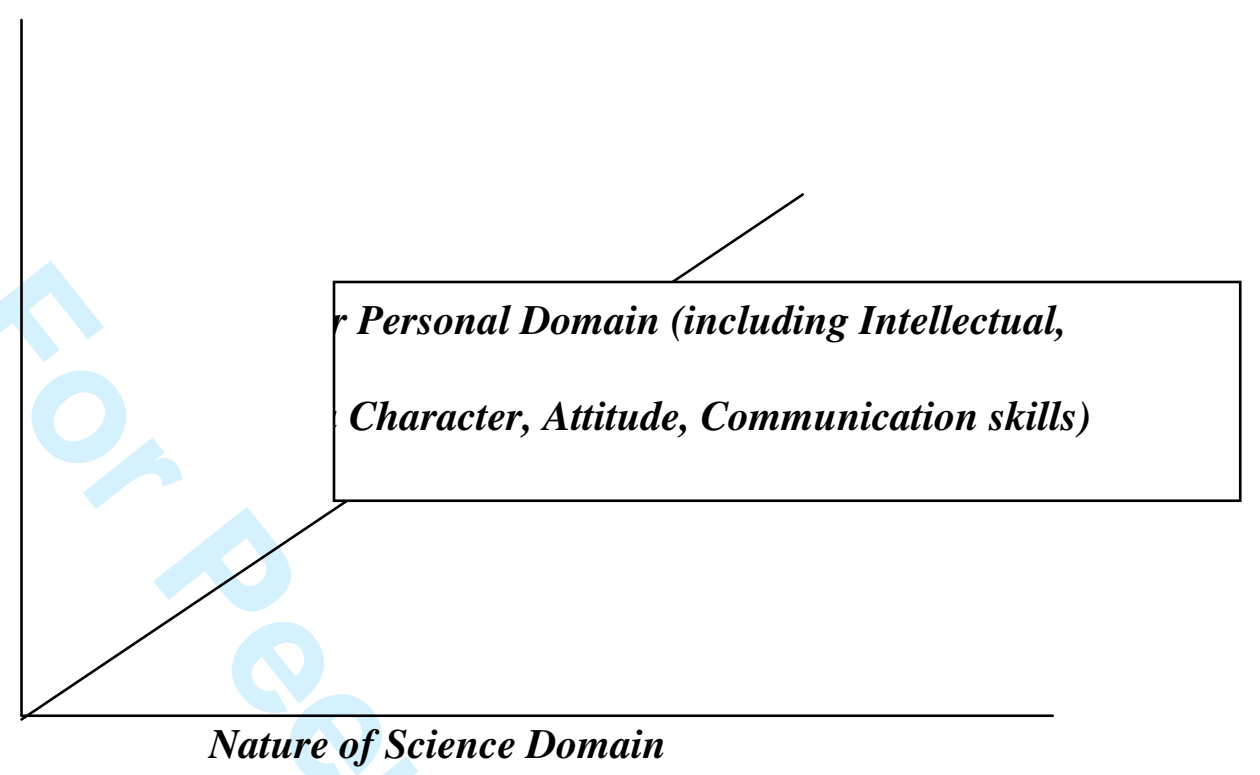

(including enquiry or investigatory skills) 